\title{
FOOD SCIENCE AND NUTRITION
}

\section{Nutritional and functional properties of Roselle (Hibiscus sabdariffa L.) seed protein hydrolysates}

\author{
Fatoumata Tounkara $^{1,2}$, Bernard Sodio ${ }^{2}$, Moses V. M. Chamba ${ }^{1}$, Guo-Wei Le $^{1 *}$ and Yong-Hui Shi ${ }^{1}$ \\ ${ }^{1}$ State Key Laboratory of Food Science and Technology, School of Food Science and Technology, Jiangnan \\ University, 1800 Lihu Road, Wuxi, 214122 Jiangsu, P.R. China \\ ${ }^{2}$ Université des Sciences, Techniques et Technologies de Bamako, FAST, Département de Biologie, Colline de \\ Badalabougou, Bamako- Rép. du Mali
}

\begin{abstract}
The nutritional and functional properties of Roselle seed protein hydrolysates (RSPH) were studied. Roselle seed protein isolates were digested (for $1.5 \mathrm{~h}$ and $3 \mathrm{~h}$ ) using pepsin followed by pancreatin. The maximum nitrogen solubility values of 94.17 and 90.8 were observed at $\mathrm{pH} 12$ and $\mathrm{pH} 10$ after $1.5 \mathrm{~h}$ and $3 \mathrm{~h}$ of hydrolysis, respectively. RSPH1.5 and RSPH3 exhibited a good foaming capacity of 310 and 300\% respectively. Furthermore, RSPH1.5 showed the best foaming stability (300\%) after 60 min compared to RSPH3 (144\%) at the same time. For both hydrolysates, the amounts of essential amino acids exceeded those recommended by the Food and Agricultural Organization/World Health Organization (2007) for humans. The emulsifying capacity of RSPH1.5 was higher than that of RSPH3 90 and $100 \mathrm{~mL} / \mathrm{g}$ respectively. RSPH1.5 possessed also the highest water holding and oil holding capacities compared to RSPH3. RSPH3 was more heat sensitive than RSPH1.5. The denaturation temperature for RSPH1.5 and $\mathrm{RSPH} 3$ were $95.80^{\circ} \mathrm{C}$ and $85.93^{\circ} \mathrm{C}$ respectively. Our results demonstrated that RSPH may be used wholly or partially to replace high-price materials like egg albumen and casein as well as a potential food ingredient.
\end{abstract}

Key words: Enzymatic hydrolysis, Functional Properties, Nutritional quality, Protein isolates, Roselle seed

\section{Introduction}

Proteins are essential constituent of any human diet, because they provide nitrogen and amino acids, which cannot be synthesized by the body (Irakoze and Zhou, 2005). In food products, protein isolates are used as additives to improve some properties, such as water-binding, foaming, gelation and emulsifying capacities, viscosity and texture. Protein isolates extracted from maize germ (Zayas and Lin, 1989), sesame seed (Lopez et al., 2003), peas (Dagorn et al., 1987), soybean and wheat proteins (Boneldi and Zayas, 1995), have been added as replacements for egg albumin to a variety of food products. To diversify its applicability in different food systems, protein isolates have been used in hydrolysed form.

Received 06 January 2013; Revised 15 May 2013; Accepted 20 May 2013; Published Online 01 January 2014

*Corresponding Author

Guo-Wei Le

State Key Laboratory of Food Science and Technology, School of Food Science and Technology, Jiangnan University, 1800 Lihu Road, Wuxi, 214122 Jiangsu, P.R. China

Email: toucoul2002@yahoo.fr
Enzymatic hydrolysis of proteins has a great of potential for modifying functional properties of food proteins. In recent years, a lot of consideration has been put on the protein hydrolysates produced by enzymatic processes. Protein hydrolysates can be classified according to their degree of hydrolysis. Protein hydrolysates with different degrees of hydrolysis can be used as flavorings in soups, sauces, and meat products (Weir, 1986). Protein hydrolysates most likely have improved functional properties compared to the original proteins and are commonly used as food ingredients (Vioque et al., 2000). In medical field, protein hydrolysates are widely used as diet supplements or hypoallergenic foods (Frokjear, 1994).

Studies have indicated that functional properties of proteins can be enhanced by enzymatic hydrolysis. Mannhein and Cheryan (1992) reported that enzymatic hydrolysis improved solubility of corn gluten meal protein compared to its unmodified form. In the case of whey and casein proteins on the other hand, Van der ven et al. (2002) found that although foam formation showed improvement after enzymatic hydrolysis and that foam stability was poorer than it was before 
modification. Findings by Qi et al. (1997) suggest that pancreatin modified soy protein exhibited better emulsifying activity index than the original protein, making it a potential ingredient in the emulsified foods formulation.

Although, some nutritional and functional properties of Roselle seed protein have been studied (data not shown), there is currently no information available especially, on the nutritional and functional properties of the Roselle seed protein hydrolysates. Therefore, this study undertaken to evaluate the nutritional and functional properties of Roselle seed protein hydrolysates obtained at different hydrolysis time for the purpose to be used in food formulation systems.

\section{Material and Methods Materials}

Seeds of $H$. Sabdariffa were obtained from Koutiala, southern region of Republic of Mali and transported to Wuxi, China. All enzymes used were of food grade. Pepsin and pancreatin were purchased from Sigma Chemical Co. (St. Louis, USA). All the other chemicals used in the experiments were from commercial sources and of analytical grade.

\section{Preparation of defatted Roselle seed flour}

Roselle seeds were cleaned by removing dust, stones, and plant debris. The seeds were milled using a laboratory scale hammer miller and the resulting powder was sieved through a 60 mesh screen until fine powder was obtained. Thereafter the powder was defatted twice with n-hexane at room temperature at a ratio of $1: 10(\mathrm{w} / \mathrm{v})$ and stirred for $7 \mathrm{~h}$ for oil extraction step. The oil-free flours was desolventized and stored in desiccator at room temperature for subsequent uses.

\section{Preparation of Roselle seed protein isolate}

Roselle seed protein isolates (RSPI) were obtained from defatted flour as reported by ElTinay et al. (1988) with some modifications. The defatted flour was dispersed in distilled water at ratio of 1:10; the $\mathrm{pH}$ was adjusted to 10 with $1 \mathrm{M}$ $\mathrm{NaOH}$ and stirred for $3 \mathrm{~h}$ at room temperature. The suspension was then centrifuged at $4000 \mathrm{rpm}$ for 20 min. The residues were re-extracted for the second time as described above. The supernatants were combined and protein was precipitated by adjusting to $\mathrm{pH} 3.5$ with $1 \mathrm{M} \mathrm{HCl}$ before centrifugation at $4000 \mathrm{rpm}$ for $20 \mathrm{~min}$. The protein isolate (precipitate) was washed twice with distilled water then resuspended in distilled water and the $\mathrm{pH}$ was adjusted to 7.0 with $1 \mathrm{M} \mathrm{NaOH}$ prior to freezedrying. The dried protein (protein isolates) was stored in desiccator at room temperature for subsequent analyses. The protein content was determined using Kjeldahl method (AOAC, 2000).

\section{Preparation of Protein hydrolysates}

To produce hydrolysates from RSPI, enzymatic hydrolysis was performed using deux enzymes (pepsin followed by pancreatin) under their optimal conditions. The RSPI samples were divided into two groups (each containing $20 \mathrm{~g}$ and $400 \mathrm{~mL}$ of water) and hydrolyzed in $500-\mathrm{mL}$ reactor under temperature and $\mathrm{pH}$ control devices. Sample 1 was hydrolyzed by pepsin $(1 \%$ at $\mathrm{pH} 2)$ for $0.5 \mathrm{~h}$ followed by pancreatin $(2 \%$ at $\mathrm{pH} 7)$ for $1 \mathrm{~h}$. Sample 2 was hydrolysed (under the same condition) by pepsin for $1 \mathrm{~h}$ followed by pancreatin $2 \mathrm{~h}$. Conditions were constantly monitored and maintained throughout the process. Upon completion of the hydrolysis, the enzymes were deactivated by heating in a boiling water bath for $10 \mathrm{~min}$. The reaction mixtures were then centrifuged at $7000 \mathrm{xg}, 4^{\circ} \mathrm{C}$ for $10 \mathrm{~min}$, and the supernatants were collected. The protein hydrolysates obtained were freeze-dried and stored at $-20^{\circ} \mathrm{C}$ for subsequent analysis. The degree of hydrolysis was determined by measuring the nitrogen content soluble in $10 \%$ trichloroacetic acid as discussed by Kim et al. (2001).

\section{Amino acids analysis}

The dried samples $(100 \mathrm{mg})$ were subjected to acid hydrolysis using $5 \mathrm{~mL}$ of $6 \mathrm{M} \mathrm{HCl}$ under nitrogen atmosphere for $24 \mathrm{~h}$ at $110^{\circ} \mathrm{C}$. The hydrolysate was washed into a $50 \mathrm{~mL}$ volumetric flask and made up to the mark with distilled water. The amino acids were subjected to RP-HPLC analysis (Agilent 1100, USA) after precolumn derivatization with o-phthaldialdehyde (OPA). Each sample $(1 \mu \mathrm{L})$ was injected into a Zorbax 80 A C18 column (i.d. 4.6X180 mm, Agilent Technologies, Palo Alto, CA, USA) at $40^{\circ} \mathrm{C}$ with detection at $338 \mathrm{~nm}$. The Amino acid composition was expressed as g per $100 \mathrm{~g}$ protein.

\section{Protein nutritional parameters}

The nutritional parameters of both hydrolysates were calculated using their amino acid composition including:

(1) Proportion of essential amino acids (E) to the total amino acids $(\mathrm{T})$ of the proteins.

(2) Amino acid score (AAS) $=$ ( $\mathrm{mg}$ of amino acid per $\mathrm{g}$ of test protein $/ \mathrm{mg}$ of amino acid per $\mathrm{g}$ of $\mathrm{FAO} / \mathrm{WHO} / \mathrm{UNU}$ standard reference pattern $) \times 100$.

(3) Predicted protein efficiency ratio (PER). The predicted PER values of Roselle protein isolates 
hydrolysates were estimated by three regression equations developed by Chavan et al. (2001).

I. $\mathrm{PER}=-0.684+0.456$ (Leu) -0.047 (Pro)

II. $\mathrm{PER}=-0.468+0.454(\mathrm{Leu})-0.105(\mathrm{Tyr})$

III.PER $=-1.816+0.435$ (Met) +0.780 (Leu) +0.211 (His)0.944 (Tyr).

\section{Nitrogen solubility (NS)}

Nitrogen solubility was determined according to the procedure of Diniz and Martin (1997), with slight modification. Samples were dissolved in distilled water $(10 \mathrm{~g} / \mathrm{L})$ and $\mathrm{pH}$ of the mixture was adjusted to $2,4,6,8,10$ and 12 with either $0.5 \mathrm{~N}$ $\mathrm{HCl}$ or $0.5 \mathrm{~N} \mathrm{NaOH}$ under continuous shaking (Lab-Line Environ-Shaker; Lab-Line Instrument, Inc., Melrose Park, IL, USA) at room temperature for $35 \mathrm{~min}$ and $25 \mathrm{~mL}$ aliquot was centrifuged at $2800 \times \mathrm{g}$ for $35 \mathrm{~min}$. A $15 \mathrm{~mL}$ aliquot of the supernatant was analyzed for nitrogen $(\mathrm{N})$ content using the Kjeldahl method and the NS was calculated according to equation:

Nitrogen solubility $(\%)=[$ Protein content in supernatant/protein content in sample] $\times 100$

\section{Differential scanning calorimetry}

Thermal properties of the hydrolysates were evaluated using Differential scanning calorimetry (DSC). Seventy milligram of various samples were dissolved into $1 \mathrm{~mL}$ of $0.05 \mathrm{M}$ phosphate buffer (pH 7.0) containing $0.1 \mathrm{M} \mathrm{NaCl}$. The protein solutions $(45 \mu \mathrm{L})$ were transferred and hermetically sealed in a stainless steel pan. The samples were heated by scanning from 20 to $200^{\circ} \mathrm{C}$ at a rate of $10^{\circ} \mathrm{C} / \mathrm{min}$ against a reference containing $45 \mu \mathrm{L}$ buffer without protein in a differential scanning calorimeter (Perkin-Elmer Corp., Norwalk, Conn., USA). Thermal denaturation temperature and enthalpy $(\Delta \mathrm{H})$ were calculated from thermograms.

\section{Water holding capacity}

The Water Holding Capacity (WHC) of the hydrolysates was determined as described by Diniz and Martin (1997) with some modifications. Triplicate samples $(0.5 \mathrm{~g})$ were placed in centrifuge tubes, dissolved with $10 \mathrm{~mL}$ of distilled water and vortexed for $30 \mathrm{sec}$. The mixture was allowed to stand at room temperature for $30 \mathrm{~min}$ and later centrifuged at $3000 \times \mathrm{g}$ for $25 \mathrm{~min}$. The supernatant was filtered using whatman Number 1 filter paper and the volume retrieved was measured. The difference between initial volumes of distilled water added to the protein sample and the flow through was determined. The results were reported as $\mathrm{mL}$ of water absorbed per gram of protein sample.

\section{Oil holding capacity}

Oil holding capacity $(\mathrm{OHC})$ was determined as described by Chakraborty (1986). One gram of each sample $\left(\mathrm{W}_{0}\right)$ was weighed into pre-weighed 15 $\mathrm{mL}$ centrifuge tubes and thoroughly mixed with 10 $\mathrm{mL}\left(\mathrm{V}_{1}\right)$ of soybean refined pure oil using Vortex mixer. Samples were allowed to stand for $30 \mathrm{~min}$. The protein- oil mixture was centrifuged at $3000 \times \mathrm{g}$ for $20 \mathrm{~min}$. The supernatant was immediately poured into a $10 \mathrm{~mL}$ graduated cylinder, and the obtained volume reading was recorded $\left(\mathrm{V}_{2}\right)$. Oil holding capacity ( $\mathrm{mL}$ of oil per $\mathrm{g}$ of protein) was calculated as:

$$
\mathrm{OHC}=\left(\mathrm{V}_{1}-\mathrm{V}_{2}\right) / \mathrm{W}_{0} .
$$

\section{Emulsifying capacity}

Emulsifying capacity of the samples was measured as described by Rakesh and Metz (1973), with some modification. One gram of each freezedried sample was transferred into a $250 \mathrm{~mL}$ beaker and dissolved in $50 \mathrm{~mL}$ of $0.5 \mathrm{~N} \mathrm{NaCl}$ and then 50 $\mathrm{mL}$ of soybeans pure oil was added. The homogenizer equipped with a motorized stirrer driven by a rheostat Ultra-T18 homogenizer ( Shanghai, China ) was immersed in the mixture and operated for $120 \mathrm{sec}$ at $10000 \mathrm{rpm}$ to make an emulsion. The mixture was transferred into centrifuge tubes, kept under a water- bath at $90^{\circ} \mathrm{C}$ for $10 \mathrm{~min}$ and then centrifuged at at $3000 \mathrm{xg}$ for 20 min. Emulsifying capacity was calculated using the equation :

$$
\mathrm{EC}=\left(\mathrm{V}_{\mathrm{A}}-\mathrm{V}_{\mathrm{R}}\right) / \mathrm{W}_{\mathrm{S}}
$$

Where:

$\mathrm{V}_{\mathrm{A}}$ is the volume of oil added to form an emulsion

$V_{R}$ is the volume of oil released after centrifugation

$\mathrm{W}_{\mathrm{S}}$ is the weight of the sample.

\section{Foaming capacity and foaming stability}

Foaming capacity (FC) was determined using the method described by Makri et al. (2005). Sample concentrates of $1 \%$ were prepared in deionized water and adjusted to $\mathrm{pH} 7.4$ with $1.0 \mathrm{~N}$ $\mathrm{NaOH}$ and $1.0 \mathrm{~N} \mathrm{HCl}$. A volume of $100 \mathrm{~mL}\left(\mathrm{~V}_{1}\right)$ of the suspension was blended for 3 min using a highspeed blender, poured into a $250 \mathrm{~mL}$ graduated cylinder, and the volume of foam $\left(\mathrm{V}_{\mathrm{F}}\right)$ was immediately recorded. Foaming capacity was calculated using the following equation:

$\mathrm{FC}(\%)=\left(\mathrm{V}_{\mathrm{F}} / \mathrm{V}_{1}\right) \times 100$

Foam stability was determined by measuring the change in volume of the foam after $60 \mathrm{~min}$. 


\section{Statistical analysis}

Results were expressed as the mean values \pm standard deviation (S.D.) of three separate determinations. The data were averages of triplicate observations and were subjected to a one way analysis of variance (ANOVA), followed by Duncan's multiple range test. The data was subjected to correlation analysis, using SPSS software (version 16.0).

\section{Results and Discussion Enzymatic Hydrolysis}

In quantitative work on protein hydrolysis it is necessary to have a measurement for the extent of hydrolytic degradation. It should be evident that the number of peptide bonds cleaved during the reaction is the parameter that most closely reflects the catalytic action of proteases (Alder-Nissen, 1986). The Degree of hydrolysis (DH) is generally used as a parameter for monitoring proteolysis and is the most widely used indicator for comparison among different protein hydrolysates. The results showed that the DH of RSPH1.5 was $15.82 \%$ which was lower than that observed at 3 hours hydrolysis time (21.56\%) (Tounkara et al., 2013b).

\section{Amino acids analysis}

The biological activity of protein is more related to its amino acid make up. In order to appreciate the physicochemical properties of the hydrolysates, amino acid composition analysis was carried out. The obtained amino acid test results were shown in Table 1 along with FAO/WHO/UNU (2007) recommended essential amino acid composition values. The results suggest that the hydrolysates contained a good proportion of all essential amino acids as reported by Sathivel et al. (2003). Glutamic acid was the major amino acid in both hydrolysates. In general, arginine, aspartic acid and glutamic acid were predominant in all the samples. The amino acid compositions of Roselle seed protein hydrolysates in this study were in agreement with the findings of El-Adawy and Khalil (1994), Tounkara et al. (2013a) for Roselle seed protein. On the other hand, the Roselle seed hydrolysates comply with the findings of Abu-Tarboush et al. (1997), this was the same for Roselle seed protein concentrates and Roselle seed protein isolates.

Table 1. Comparative amino acid profiles of the RSPH1.5 and RSPH3 (g/100g of protein).

\begin{tabular}{llll}
\hline Amino acids ${ }^{\text {a) }}$ & RSPH1.5 & RSPH3 & FAO /WHO Child (Adult) \\
\hline Essential amino acids & & & $4.8(4.5)$ \\
\hline Lysine & 4.48 & 4.04 & $1.6(1.5)$ \\
Histidine & 2.34 & 2.28 & $6(5.9)$ \\
Leucine & 7.90 & 6.26 & $3(3)$ \\
Isoleucine & 3.82 & 3.93 & \\
Phenylalanine & 5.41 & 4.31 & $4.1(3.8)$ \\
Phenylalanine+Tyrosine & 8.19 & 6.33 & $2.3(1.6)$ \\
Methionine & 1.79 & 2.26 & $2.9(3.9)$ \\
Methionine+Cystein & 3.04 & 3.88 & $2.5(2.3)$ \\
Valine & 5.11 & 5.61 & \\
Threonine & 3.25 & 3.76 & \\
\hline Non-essential amino acids & & & \\
\hline Glycine & 4.03 & 4.59 & \\
Cysteine (Cys-S) & 1.25 & 1.62 & \\
Aspartic acid & 10.37 & 11.69 & \\
Glutamic acid & 23.48 & 24.78 & \\
Serine & 4.43 & 4.48 & \\
Arginine & 10.37 & 11.69 & \\
Alanine & 4.45 & 4.74 & \\
Tyrosine & 2.78 & 2.02 & \\
Proline & 4.73 & 5.56 & \\
a) Data are mean of 3 replications & &
\end{tabular}




\section{Protein nutritional parameters}

The quality (nutritional or nutritive value) of protein in human diet depends on the level at which it can provide the amount of essential amino acids required by the body for growth and maintenance (Zhu et al., 2006). In this study, amino acid composition was used as a basis for estimating the nutritional quality of Roselle seed protein hydrolysates. Results of the ratio of essential to total amino acids (E/T), amino acid score (AAS) and protein efficiency ratio (PER) of the hydrolysates are shown in Table 2 . In all samples the ratio of essential to total amino acids was higher than 36\% (the recommended value by $\mathrm{FAO} / \mathrm{WHO} / \mathrm{UNU}$ ), and 1.5 hydrolysates had the highest ratio of $41.12 \%$ (Table 2). In general PER below 1.5 implies a protein of low or poor quality, while PER between 1.5 and 2.0 indicates an intermediate protein quality and then PER above 2.0 indicates protein of a high quality (Friedman, 1996). The predicted PER values of all the samples were in the range of high quality (Table 2). The AAS results showed that amino acid compositions were well balanced in both hydrolysates and their values were almost the same as those recommended by Agricultural Organization/World Health Organization for adult requirements (FAO, 2007).

\section{Differential scanning calorimetry}

Differential scanning calorimetry is a method that has been used extensively on protein denaturation in various food systems to obtain data for heat capacity, enthalpy and entropy (thermodynamic) and reaction rate and activation energy (kinetic) due to its rapidity and easiness (Ryan et al., 2008; Foh et al., 2011). The thermal properties of the two different hydrolysates were investigated to examine the impact of hydrolysis time on the peptide conformation. The knowledge on thermal properties of protein is important for strategizing food-processing and designing heatprocessing (Ju et al., 2001). Because functional properties of protein meal products are greatly influenced by their conformation, therefore, differential scanning calorimetry as a technique highly sensitive to conformational changes is often applied to protein hydrolysates and related products (Goreinstein et al., 1996). Thermal properties of the RSPH1.5 and the RSPH3 were given in Table 3 . The denaturation temperature and enthalpy of the RSPH1.5 and the RSPH3 were $95.80^{\circ} \mathrm{C}, \quad 5.31 \mathrm{~J} / \mathrm{g}$ and $85.93^{\circ} \mathrm{C}, \quad 3.65 \mathrm{~J} / \mathrm{g}$, respectively. The result shows that both hydrolysates were less heat sensitive. These results means, that the RSPH could be subjected to acceptable heat treatment during processing conditions without undergoing denaturation.

Table 2. Nutritional parameters of the different Roselle (Hibiscus sabdariffa L.) protein seed hydrolysates.

\begin{tabular}{lll}
\hline Parameters ${ }^{\text {a) }}$ & RSPH1.5 & RSPH3 \\
\hline E/T \% & 41.12 & 37.81 \\
Estimated of PER & & \\
I & 2.69 & 1.91 \\
II & 2.83 & 2.16 \\
III & 2.95 & 2.63 \\
Amino acid scores & & \\
Leucine & 131.67 & 104.33 \\
Histidine & 146.25 & 142.25 \\
Threonine & 130.00 & 150.4 \\
Valine & 176.20 & 193.45 \\
Met + Cys & 132.17 & 168.69 \\
Isoleucine & 127.33 & 131.00 \\
Phe+Tyr & 199.02 & 154.39 \\
Lysine & 93.33 & 84.16 \\
\hline Data are mean & 3 replication
\end{tabular}

a) Data are mean of 3 replications. E/T $=$ Amount of essential amino acids (E) to total amino acids (T), PER = protein efficiency ratio.

Table 3. Thermal properties of Roselle seed protein hydrolysates.

\begin{tabular}{lll}
\hline \multirow{2}{*}{ DSC Measure ${ }^{\text {a) }}$} & \multicolumn{2}{l}{ Sample } \\
\cline { 2 - 3 } & RSPH1.5 & RSPH3 \\
\hline $\mathrm{T}_{\mathrm{o}}$ & 78.44 & 60.47 \\
$\mathrm{~T}_{\mathrm{p}}$ & 86.95 & 75.45 \\
$\mathrm{~T}_{\mathrm{e}}$ & 95.80 & 85.93 \\
$\Delta \mathrm{H}(\mathrm{J} / \mathrm{g})$ & 5.3176 & 3.651 \\
$\operatorname{Ar}(\mathrm{Mj})$ & 16.006 & 25.525 \\
\hline a)
\end{tabular}

a) Data are mean of 3 replications. To: Start Temperature; Tp: Peak Temperature; Te: End Temperature; $\Delta H$ : Delta H; Ar: Area

\section{Nitrogen solubility (NS)}

Nitrogen solubility is used to measure protein hydro solubility. Nitrogen solubility is one of the most essential functional properties due to its impact on the other properties. As indicated in Figure 1, the nitrogen solubility of both hydrolysates was $\mathrm{pH}$ dependent. The curves showed that the solubility of the hydrolysates reached their minimum values of $63.85 \%$ and $73.85 \%$ at $\mathrm{pH} 4.0$ for the RSPH1.5 and the RSPH3 respectively, while increased at high $\mathrm{pH}$. The lowest solubility of all hydrolysates was achieved at $\mathrm{pH} 4.0$ because the isoelectric point of Roselle seed protein is between 3.5 and 4 , and the minimum solubility usually occurs at isoelectric point. Thus, the hydrolysis might be responsible for the 
increased solubility at the isoelectric point and at other $\mathrm{pH}$ levels as a result of shortening of molecular chains and the increase in the amount of polar groups (Chobert et al., 1988; Nielsen, 1997; Slattery and Fitzgerald, 1998). This trend in solubility is in agreement with previous reports (Clemente et al., 1999; Aluko and Monu, 2003). The high nitrogen solubility of different hydrolysates ( 80 to $90 \%$ ) would make them suitable for food applications (Yiqiang et al., 2000). The values of protein solubility at various $\mathrm{pH}$ may be helpful for predicting how protein hydrolysate would perform when used in food systems.

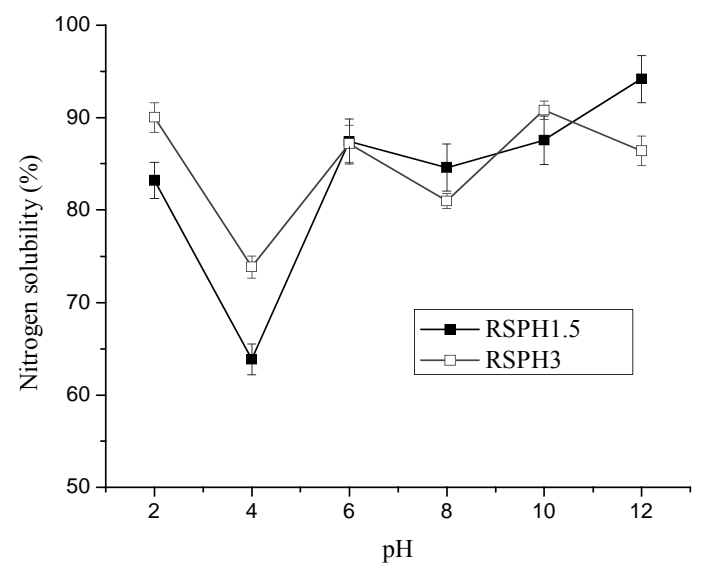

Figure 1. Nitrogen solubility of the two Roselle seed protein hydrolysates.

Values represent the means \pm SD of triplicates.

\section{Water holding capacity}

Water and oil interactions with proteins are essential in food systems as they have a great impact on food organoleptical attributes. Protein conformation, amino acid composition and surface hydrophobicity/ polarity are some of the intrinsic factors that affect water holding (WHC) capacity of food proteins (Barbut, 1999). Water holding capacity is the ability of protein to absorb water and retain it against a gravitational force within its matrix. The WHC of the RSPH1.5 and the RSPH3 were 2.5 and $2 \mathrm{~mL} / \mathrm{g}$ (Table 4) respectively. The result of WHC of the hydrolysates obtained from this study was comparable to those previously reported by Foh et al. (2010). Water holding capacity is a valuable factor for protein additives used in food systems. The WHC of the hydrolysates can be used to determine how those proteins can be added into food formulation systems and how they can replace animal proteins traditionally used (Zayas and Lin 1989).

\section{Oil holding capacity}

Oil holding capacity (OHC) may be defined as the ability of a substance to absorb and retain oils. It is an important property in food processing because it influences organoleptical aspects of food products. The OHC of RSPH1.5 and RSPH3 were $5.6 \mathrm{~mL} / \mathrm{g}$ and $4.9 \mathrm{~mL} / \mathrm{g}$, respectively (Table 4 ). It is proposed that high oil absorption capacity of Roselle seed protein hydrolysates may give an advantage for their consideration in the formulation of food products such as cake, sausages, salad dressings and mayonnaise. Wasswa et al. (2007) also produced protein hydrolysates with $\mathrm{OHC}$.

\section{Emulsifying capacity}

Food emulsions, the mixtures of immiscible liquids (water and oil), are usually thermodynamically unstable. In food systems such as salad dressings, their formation and stability are very important. Proteins and lipids commonly interact in food systems. The proteins' ability to stabilize emulsions is vital. Formation of emulsions occurs due to the presence of hydrophilic and hydrophobic groups of proteins. This primarily depends on diffusion of peptide chains at water-oil interfaces. Hydrolysates with smaller molecular sizes and high solubility facilitate that diffusion and improve the protein-lipid interaction. As shown in Table 4, all hydrolysates were good emulsifiers with EC of $100 \mathrm{~mL} / \mathrm{g}$ and $90 \mathrm{~mL} / \mathrm{g}$ for the $\mathrm{RSPH}$ 1.5 and RSPH3 respectively. Roselle seed protein digested using pepsin followed by pancreatin were degraded into peptides (oligopeptides and polypeptides), consequently enhancing the protein solubility, emulsion capacity and stability. Hydrolysis was effective in improving the EC of hydrolysates. Related findings have indicated that enzymatic hydrolysis of tilapia (Foh et al., 2010) and grass carp skin (Wasswa et al., 2007) produced hydrolysates with higher emulsifying capacity.

Table 4. Functional properties of RSPH.

\begin{tabular}{|c|c|c|}
\hline Functional properties $^{\text {a) }}$ & RSPH1.5 & RSPH3 \\
\hline $\begin{array}{l}\text { Water holding capacity } \\
(\mathrm{mL} / \mathrm{g})\end{array}$ & $2.5 \pm 0.02^{\mathrm{a}}$ & $2.00 \pm 0.10^{\mathrm{b}}$ \\
\hline $\begin{array}{l}\text { Oil binding capacity } \\
(\mathrm{mL} / \mathrm{g})\end{array}$ & $5.6 \pm 0.30^{\mathrm{a}}$ & $4.9 \pm 0.14^{b}$ \\
\hline $\begin{array}{l}\text { Emulsifying capacity } \\
(\mathrm{mL} / \mathrm{g})\end{array}$ & $100 \pm 4.0^{\mathrm{a}}$ & $90 \pm 3.10^{b}$ \\
\hline Foaming capacity $(\%)$ & $310 \pm 3.5^{\mathrm{a}}$ & $300 \pm 4.0^{\mathrm{b}}$ \\
\hline
\end{tabular}




\section{Foaming capacity and foaming stability}

The foam formation is equivalent to the emulsion formation. The ability of proteins to form stable foams is an important property. Increase in net charge of the protein likely increases the flexibility of the protein and weakens hydrophobic interactions. Results in Table 4 suggested that all the hydrolysates had good foaming capacities (FC) of $310 \%$ and $300 \%$ for the RSPH1.5 and RSPH3, respectively. These results corroborate with the findings of Puski (1975), Alder-Nissen (1986), and Wang et al. (2008), who reported that enzymatically-modified food proteins improved foaming properties. Moreover, the RSPH1.5 showed more stable foam compared to the RSPH 3 (300 and $144 \%$ at $60 \mathrm{~min}$, respectively) (Figure 2). The FC of the hydrolysates was improved by hydrolysis. Nevertheless, it is clear that the FC may depend on the protein structure, molecular size and hydrophobicity of the hydrolysate (Martin et al., 2002), which also depend highly on the hydrolysis procedure and the parent protein from which they are obtained. The effect of hydrolysis on foam stability is dependent on the degree of hydrolysis (Althouse et al., 1995; Mutilangi et al., 1996; Slattery and Fitzgerald, 1998). The short chain molecules form a wicker interaction network, which result in to a less stable foam.

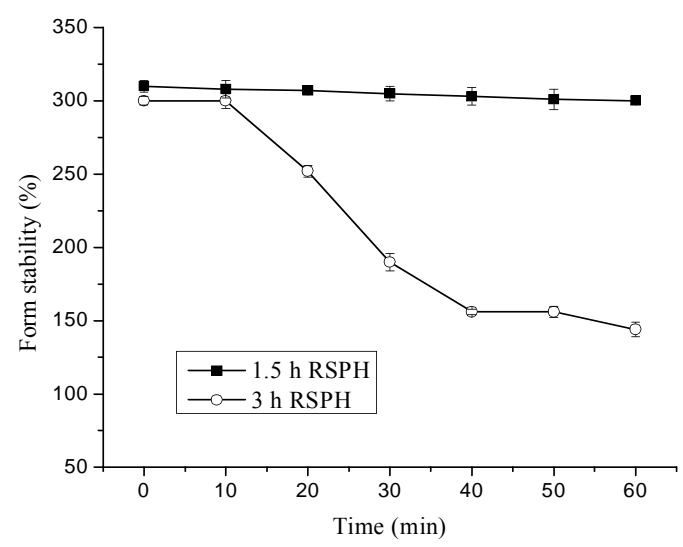

Figure 2. Foaming stability of Roselle seed protein hydrolysates.

Values represent the means $\pm \mathrm{SD}$ of triplicates

\section{Conclusion}

The primary functionality of Roselle seed protein hydrolysates is due to its soluble peptide content. Roselle seed protein hydrolysates have high nitrogen solubility, good emulsifying capacity, WHC, OHC, foaming capacity and foam stability. The proportion of essential amino acids of both samples was higher than the recommended values by $\mathrm{FAO} / \mathrm{WHO}$. All the estimated nutritional parameters based on amino acids composition showed that RSPH has a good nutritional value. These results proposed that RSPH could be useful as whole or partial replacement of high-price protein sources such as egg albumin and casein.

\section{Acknowledgements}

This research was supported by the National Science Foundation of China (No. 30671525), the National High Technology Research and Development Program ("863" Program) of China (No. 2007. AA10Z325) and 111 project-B07029. The authors wish to thank Mr Coulibaly Oumar (Bamako, Mali) for sending Roselle seeds to Wuxi, P.R.China.

\section{References}

Abu-Tarboush, H. M., A. A. Ahmed, and H. A. Kahtani. 1997. Some nutritional and functional properties of Karkade (H. sabdariffa) seed products. Cereal Chem. 74:352- 355.

Adler-Nissen, J. 1986. Enhancing the functionality of food proteins by enzymatic modification, In: Barking. pp 110-169. Enzymatic Hydrolysis of Food Proteins'. Elsevier Applied Science Publishers. U.K.

Althouse, P.J., P. Dinakar and A. Kilara. 1995. Screening of proteolytic enzymes to enhance foaming of whey protein isolates. J. Food Sci. 60:1110-1112.

Aluko, R.E. and E. Monu. 2003. Functional Properties and bioactive properties of quinoa seed protein hydrolysates. J. Food Sci. 68:1254-1258.

Amadou, I., T. Amza, M. B. K. Foh, M. T. Kamara and G. W. Le. 2010. Influence of Lactobacillus plantarum Lp6 fermentation on the functional properties of soybean protein meal. Emir. J. Food Agric. 22:456-465.

AOAC. 2000. Official Method of Analysis. 17th ed. Association of official Analytical Chemists, Arlington, VA.

Barbut, S. 1999. Determining water and fat holding, In: G.M. Hall (Eds). pp. 186-225. Methods of testing protein functionality. Blackie Academic and Professional. N. Y.

Boneldi, V. and J. F. Zayas. 1995. Foaming properties of selected plant and animal proteins. J. Food Sci. 60:1025-1029. 
Chavan, U.D., D. B. Mckenzie and F. Shahidi. 2001. Functional properties of protein isolates from beach pea (Lathyrus maritius L.). Food Chem. 74: 177-187.

Chobert, J.M., M. Z. Sitohy and J. R. Whitake. 1988. Solubility and emulsifying properties of caseins modified enzymatically by Staphylococcus aureus V8 protease. J. Agric. Food Chem. 36:220-224.

Clemente, A., J. Vioque, R. Sánchez-Vioque, J. Pedroche, J. Bautista and F. Millan. 1999. Protein quality of chickpea (Cicer arietinum L.) protein hydrolysates. Food Chem. 67:269274.

Dagorn-Scaviner, C., J. Gueguern and J. Lefebvre. 1987. Emulsifying properties of pea globulins as related to their adsorption behavior. J. Food Sci. 52:335-341.

Diniz, F. M. and A. M. Martin. 1997. Effects of the extent of enzymatic hydrolysis on the functional properties of shark protein hydrolysate. LWT- Food Sci Technol. 30: 266-272.

El- Adawy, T. A. A. H. and Khalil. 1994. Characteristic of roselle seeds as a new source of protein and lipid. J. Agric. Food Chem. 42:1896-1900

El-Tinay, A. H., A. M. Nour, S. H. Abdel-Karim and S. O. Mahgoub. 1988. Aqueous protein and gossypol extraction from glanded cottonseed flour: Factors affecting protein extraction. Food Chem. 29: 57-63.

FAO. 2007. Protein and Amino Acid Requirements in Human Nutrition. Report of a joint WHO/FAO/UNU expert consultation, WHO technical report series, No. 935. The World Health Organization: Geneva, Switzerland.

Foh., M. B. K., I. Amadou, B. M. Foh, M. T. Kamara and W. Xia. 2010. Functionality and antioxidant properties of tilapia (Oreochromis niloticus) as influenced by the degree of hydrolysis. Int. J. Mol. Sci. 11:1851-1869.

Foh., M. B. K., M. T. Kamara, I. Amadou, B. M. Foh and W. Xia. 2011. Chemical and physicochemical properties of tilapia (Oreochromis niloticus) fish protein hydrolysate and concentrate. Int. J. Biol. Chem. 5:21-36.
Friedman, M. 1996. Nutritional value of proteins from different food sources. J. Agric. Food Chem. 44:26-29.

Frokjear, S. 1994. Use of hydrolysates for protein supplementation. Food Technol. 48:86-88.

Gorinstein, S., M. Zemser and O. Paredes-Lopez. 1996. Structural stability of globulins. J. Agric. Food Chem. 44:100-105.

Irakoze, P. C. and H. Zhou. 2005. Enzymatic hydrolysis of defatted wheat germ by proteases and the effect on the functional properties of resulting protein hydrolysates. J. Food Biochem. 29:13-26.

Ju, Z. Y., N. S. Hettiarachchy and N. Rath. 2001. Extraction, denaturation and hydrophobic properties of rice flour proteins. J. Food Sci. 66:229-232.

Kim, S. K., Y. T. Kim, H. G. Byun, K. S. Nam, D. S. Joo and F. Shahidi. 2001. Isolation and characterization of antioxidative peptides from gelatin hydrolysate of Alaska pollack skin. J. Agric. Food Chem. 49:1984-1989.

Lopez, G., I. Flores, A. Galvez, M. Quirasco and A. Farres. 2003. Development of a liquid nutritional supplement using a Sesamum indicum L. protein isolate. LWT- Food Sci Technol.. 36:67-74.

Makri, E., E. Papalamprou and G. Doxastakis. 2005. Study of functional properties of seed storage proteins from indigenous European legume crops (lupin, pea, broad bean) in admixture with polysaccharides. Food Hydrocoll. 19: 583-594.

Mannheim, A. and M. Cheryan. 1992. Enzymemodified proteins from corn gluten meal: preparation and functional properties. J. Am. Oil Chem. Soc. 69:1163-9.

Martin, A. H., K. Grolle, M. A. Bos, M. A. C. Stuar and T. van Vliet. 2002. Network forming properties of various proteins adsorbed at the air/water interface in relation to foam stability. J. Colloid Interface Sci. 254:175-183.

Mutilangi, W. A. M., D. Panyam and A. Kilara. 1996. Functional properties of hydrolysates from proteolysis of heat-denatured whey protein isolate. J. Food Sci. 61:270-274.

Nielsen, P. M. 1997. Functionality of protein hydrolysates, In: S. Damadoran and A. Paraf 
(Eds.). pp. 443-472. Food Proteins and Their Applications'. Marcel Dekker. N.Y.

Ochiai, K.,Y. Kamata and K. Shibasaki. 1982. Effect of tryptic digestion on emulsifying properties of soy protein. Agric. Biol. Chem. 42:91-96.

Puski, G. 1975. Modification of functional properties of soy proteins by proteolytic enzyme treatment. Cereal Chem. 52:655-664.

Qi, M., N. S. Hettiarachchy and U. Kalapathy. 1997. Solubility and emulsifying properties of soy protein isolates modified by pancreatin. J. Food Sci. 62:1110-1115.

Rakesh, J. and A. Metz. 1973. Acid precipitated fish Protein isolate exhibits good functional properties. Food Product Dev. 7: 18-24.

Ryan, M., E. McEvoy, S. Duignan, C. Crowley, M. Fenelon, D.M. O'Callaghan and R. J. FitzGerald. 2008. Thermal stability of soy protein isolate and hydrolysate ingredients. Food Chem. 108:503-510.

Sathivel, S., P. J. Bechtel, J. Babbitt, S. Smiley, C. Crapo and K. D. Reppond, 2003. Biochemical and functional properties of herring (clupea harengus) byproduct hydrolysates. J. Food Sci. 68:2196-2200

Shahidi, F., X. Q. Han and J. Synowiecki. 1995. Production and characteristics of protein hydrolysates from capelin (Mallotus villosus). Food Chem. 53:285-293.

Slattery, H. and R. J. Fitzgerald. 1998. Functional properties and bitterness of sodium caseinate hydrolysates prepared with a Bacillus proteinase. J. Food Sci. 63:418-422.

Tounkara, F., T. Amza, C. Lagnika, G. W. Le and Y. H. Shi. 2013a. Extraction, characterization, nutritional and functional properties of Roselle (Hibiscus sabdariffa Linn) Seed Proteins. Songklanakarin J. Sci. Technol. In press.

Tounkara, F., M. Bashari, G. W. Le and Y. H. Shi. 2013b. Antioxidant activities of Roselle (Hibiscus sabdariffa L.) seed protein hydrolysates and its derived peptide fractions. Int. J. Food Prop. In press.

Van der Ven, C., H. Gruppen, D. B. A. de Bont and A. G. J. Voragen. 2002. Correlations between biochemical characteristics and foamforming and -stabilizing ability of whey and casein hydrolysates. J. Agric. Food Chem. 50:2938-46.

Vioque, J., R. Sánchez-Vioque, A. Clemente, J. Pedroche and F. Millán. 2000. Partially hydrolyzed rapeseed protein isolates with improved functional properties. JAOCS. 77:14.

Wang, J., M. Zhao, X. Yang and Y. Jiang. 2008. Improvement on functional properties of wheat gluten by enzymatic hydrolysis and ultrafiltration. J. Cereal Sci. 44:93-100.

Wasswa, J., J .Tang and X. H. Gu. 2007. Optimization of the production of hydrolysates from grass carp (Ctenopharyngodon idella) skin using Alacalase. J. Food Biochem. 32:460-473.

Weir, G. S. D. 1986. Protein hydrolysates as flavourings, In: B. J. F. Hudson (Ed). pp. 3578 Developments in Food Protein's. Elsevier. U. K.

Yiqiang, G., S. Aidong, N. Yuanying and C. Tongyi. 2000. Some nutritional and functional properties of defatted wheat germ protein. J. Agric. Food Chem. 48:6215-6218.

Zayas, J. F. and M. Lin. 1989. Food applications of corn germ protein flour. J. Food Sci. 56:11351145 .

Zhu, K. X., H. M. Zhou and H. F. Qian. 2006. Proteins extracted from defatted wheat germ: nutritional and structural properties. Cereal Chem. 83:69-75. 